\title{
Opportunities and Challenges of Digital Learning Media During the Covid-19 Pandemic in Primary School
}

\author{
Jamilah*, Tri Sukitman, Moh. Fauzi \\ STKIP PGRI Sumenep, Jalan Trunojoyo Gedungan Sumenep, Jawa Timur, 69451, Indonesia
}

\begin{abstract}
Received: May 07, 2021
Revised: July 16, 2021

Abstract

This research is focused on digital learning, barriers faced by teachers, and various approaches to overcome various obstacles faced by teachers in Accepted: September 13, 2021 implementing digital learning during the covid 19 pandemic. This research was descriptive quantitative research. Data collection was conducted by distributing questionnaires to teachers through Google form. The questionnaire consisted of a Likert scale of 1-5, which aims to look at the digital learning process during the pandemic in primary schools in Sumenep. The data collection consisted of questionnaires given to 100 teachers and interviews to 7 teachers to describe information related to the focus of research. The data was analyzed by using descriptive analysis. From the results of questionnaires and interviews with teachers, there are some obstacles experienced by teachers, among others, the low ability of teachers in applying information technology, economic factors of parents, unstable internet networks, and the absence of information technology training provided by the school. On the other hand, over time teachers are able to implement digital learning independently and adapt to the surrounding environment and understand the various characteristics of students in utilizing digital in learning during the COVID-19 pandemic.
\end{abstract}

Keywords: digital learning, covid-19 pandemic, primary education

(*) Corresponding Author: $\quad$ jamilah@stkippgrisumenep.ac.id

How to Cite: Jamilah, Sukitman, T., \& Fauzi, M. 2021. Opportunities and challenges of digital learning media during the covid-19 pandemic in primary school. Formatif: Jurnal Ilmiah Pendidikan MIPA, 11 (2): 191-200. http://dx.doi.org/10.30998/formatif.v11i2.9732

\section{INTRODUCTION}

At the end of 2019, Corona virus outbreak first occurred in the Chinese city of Wuhan. Since then, the city of Wuhan has made a policy to tackle the spread of the virus by changing the online learning model. The goal is to estimate the effect of physical distancing measures on the development of Corona virus spread, expected to provide insights for the whole world. Education with science and technology is closely related. The Industrial Revolution 4.0 era is an era marked by the advances in science and technology that have an impact on the joints of life, one of which is the field of education.

However, various developments of science and technology that have been adopted education facilitate teaching materials to support the development of science so that institutional arrangements, institutional organizational structures, mechanisms of action become better with the use of technology as it is today. Knowledge and technology due to the urgent need for education, many technologies from various sciences will soon be adopted 
into educational provisions. The importance of technology in education is one of the bases of education that must be understood.

Based on the results of research on COVID-19, according to the interviews with parents, it is stated that COVID has a strong impact based on the interviews in revealing the challenges faced by the students' parents who work and study at home during COVID-19 pandemic not only providing practical but also emotional challenges to these students' parents, as well as about students who are passionate and independent during online learning during COVID-19 (Jamilah, 2020a). The steps taken to prevent the spread of COVID-19 are implementing social and physical distancing policies, and temporarily closing schools (Fong, et. al., 2020).

Online learning has many varieties and types, it was developed since 2002 (Chaeruman, Wibawa and Syahrial, 2020; Selwyn, 2016) and is form of technology. Educational online transformation in learning transforms conventional learning model into digital form so that teachers have their own challenges and opportunities in learning (Harjanto and Sumunar, 2018). Online learning uses digital technology.

This is in line with the opinion of Lathipatud and Zuhdi (2018) stating that digital technology or information technology is one of the solutions for the implementation of online lectures. Many digital media are used by educators to perform online learning. Information technology to support the implementation of online learning during this pandemic includes elearning, learning house, Edmodo, EdLink, Moodle, and Google Classroom. Students must be facilitated in the implementation of online learning. After three months of the implementation of online learning, many students complain about online learning because of the very limited online facilities the students have.

There is still not much research on the obstacles on using online learning during the pandemic. Mailizar, Almanthari, Maulina and Bruce (2020) did the research on remote elearning in Indonesia, but the participants who cultivate are math teachers. Therefore, schools that do not yet have enforcement in e-learning, especially for teachers, do not understand how to use the online application (Zaharah and Kirilova, 2020).

This literature review has been conducted by Sudarsana, et. al. (2019) who found the results of research on a number of opportunities and challenges faced in the use of information technology to support the processes in educational activities. The results of research studies from Juliantari, et. al. (2018) have also studied the use of information technology in learning evaluation activities through the use of interactive games.

The results of these studies indicate that information technology is effectively used to support learning and evaluation appropriately in its use with the support of various adequate facilities. Based on the results of the study, the use of digital technology can be used in teaching and learning in the classroom. This exploratory research shows the results regarding the choices of teachers and students in choosing the use of digital technology in the learning process. There are differences in the use of digital technology among students and teachers. In addition, the subjects touched by this information technology are different, so there are new things that certainly can support the two previous studies.

Based on the description above, it is hoped that teachers will be able to adapt to technology development, so that the role of such technology can overcome various problems in during the COVID-19 pandemic. Indeed, this is the opportunity and challenge in the world of education. This research focuses on digital learning, the obstacles faced by teachers and approaches to overcoming various obstacles in the implementation of digital learning. The hope in learning with online models is to be a solution that can help learning in the midst of 
the COVID-19 pandemic and answering the challenges of the times and the rapid advancement of information technology.

\section{METHODS}

This research was a descriptive quantitative research. Data collection was conducted by distributing questionnaires to teachers through Google form. The questionnaire consisted of a Likert scale of 1-5, which aimed to look at the digital learning process during the pandemic in primary schools. The instrument was sent via WhatsApp, either through a personal WhatsApp or a teacher's WhatsApp group. The object of this research was primary school teachers in Sumenep Regency, Indonesia. The data collection was carried out through questionnaires from 100 teachers and interviews from 7 teachers to obtain in-depth information regarding the focus of this research.

The questions relate to the implementation of digital learning, including the knowledge and ability to use digital media, selecting and planning students' learning and readiness for distance learning and the obstacles faced in digital learning during the pandemic. The data was analyzed by using descriptive analysis. The results of the study were tabulated in graphs of both table and table images. Data analysis was conducted through data collection, data reduction, conclusion images and verification (Miles, Huberman and Saldana, 1994).

\section{RESULTS \& DISCUSSION}

\section{Results}

Quantitative data from digital use instruments in online learning during the pandemic. Online learning is one of the effective steps in learning during the COVID-19 pandemic (Basilaia and Kvavadze, 2020; Bauerlein, 2008; Taha, Abdalla and Wadi, 2020). The distant learning process can be carried out by teachers by means of online, offline, and blended learning. This research shows that the obstacles in implementing e-learning in higher education include: lecturers have mastered it basic skills to support e-learning (Al-rahmi, Othman and Mi Yusuf, 2015; Ash, Stavri and Kuperman, 2003)

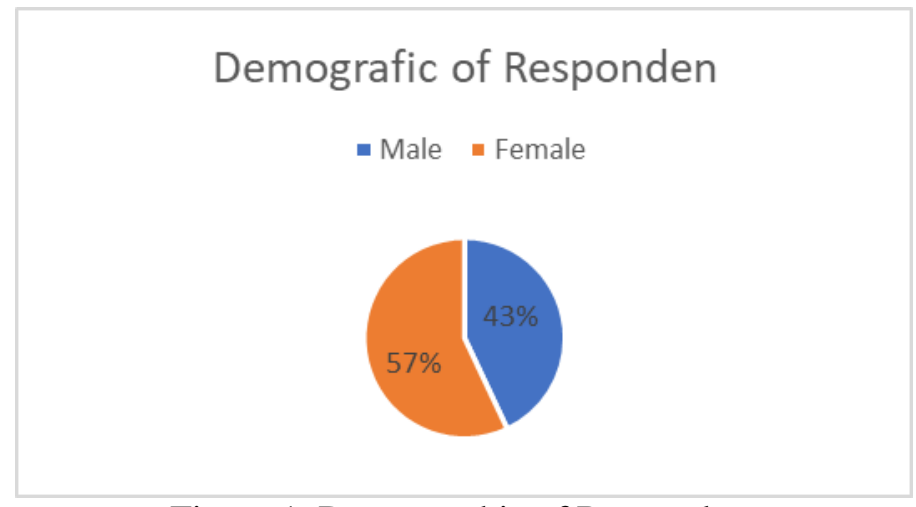

Figure 1. Demographic of Respondent 
The demographic of respondent from this study can be seen in Figure I that presents the results of male $43 \%$ and female $57 \%$. One of the ways that must be mastered by the teacher is about the issues of IT and learning models that are carried out in the learning process. One of them is that teachers can operate learning media devices such as the use of laptop, WhatsApp, and various other types of learning media so that the learning process can run well whatever the form of the learning process, whether online, offline or blended learning, must still be implemented.

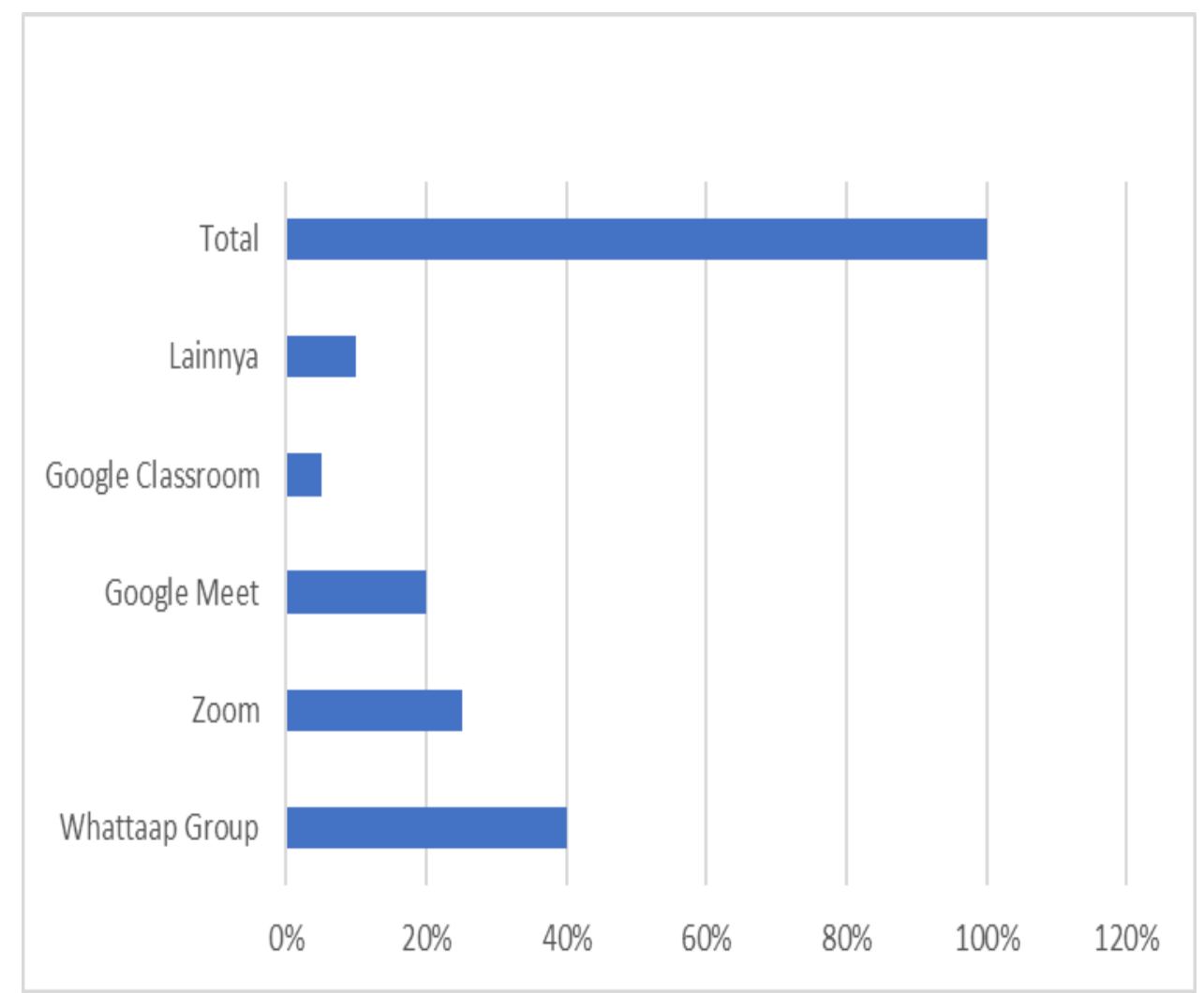

Figure 2. The Platform Used in the Online Learning at Primary School

Figure 2 shows some applications used by teachers in online learning, namely: Google Classroom, Zoom, WA group and Google Meet. $40 \%$ of teachers use WhatsApp in online learning process in pandemic. One of the evaluations of online disclosure is to carry out the assessment activities. This becomes important because evaluation is an important entity in the teaching and learning process. The purpose of this assessment is used to see the development of competencies possessed by students, so that teachers need to provide an assessment. This pedagogic ability is also needed by the teacher to sort the materials that will be conveyed to students by managing and organizing each material on the subject. 


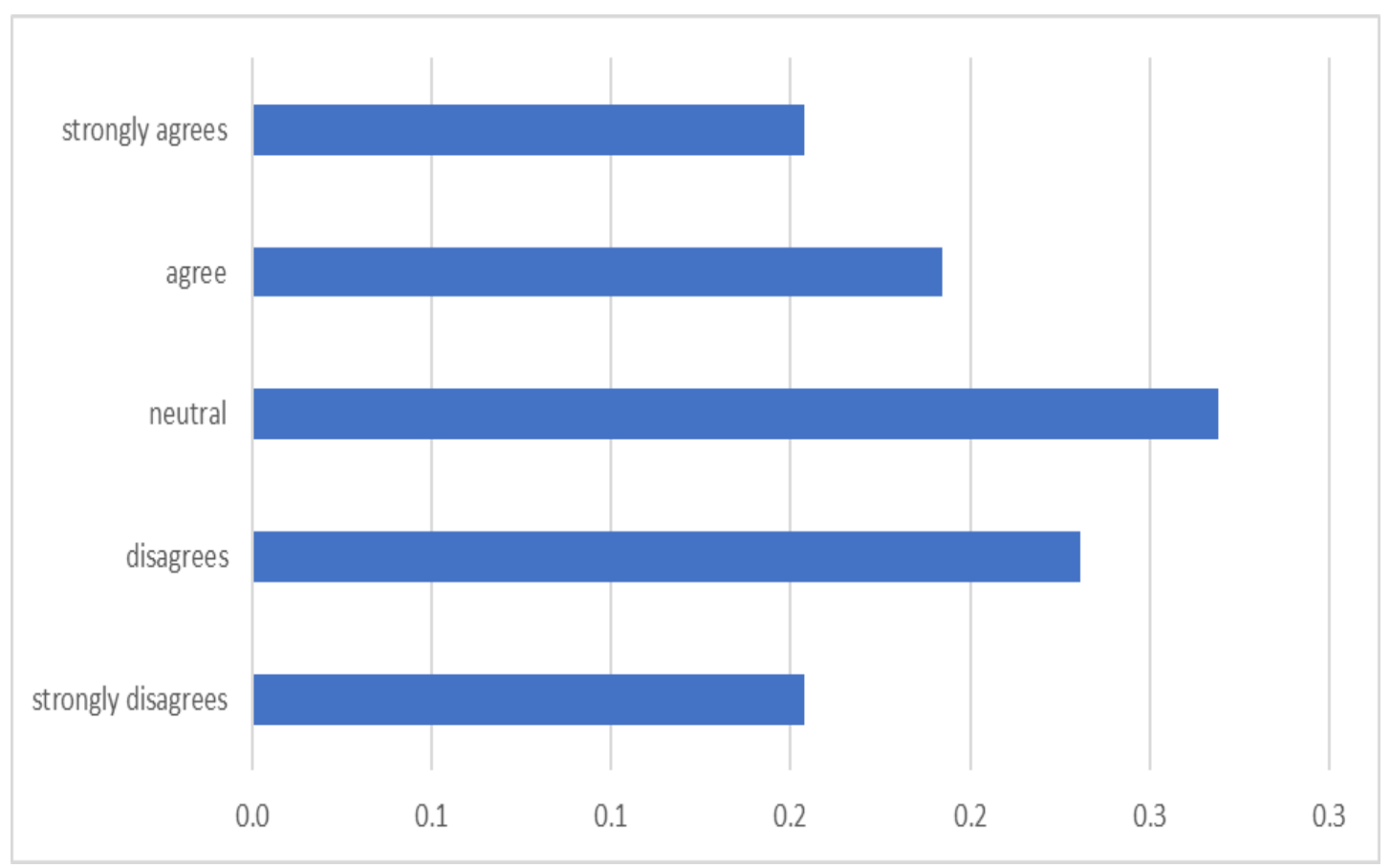

Figure 3. Online Learning Assessment

Figure 3 points out that many teachers are the most neutral in online learning assessments. It is inconceivable how the condition of the generation during this pandemic, there will be a decrease in learning achievement for students. Tjandra (2020) states that teachers are required to be innovative in the use of learning media with an online model. This means that in the learning process the teacher only facilitates learning media such as modules, textbooks, supporting books, and internet access. To overcome the various problems above, the readiness of teachers, students, parents and schools must be able to learn various platforms in using learning media. This will have a positive impact on the learning process during the pandemic (Wisudawati, 2020).

\section{Discussion}

It has been almost a year that the Corona virus has hit countries in the world, including the education world. Various efforts have been taken by the government to prevent the spread of COVID-19. One of them is by the socialization of social distancing movements. This is done to reduce and even to break the chain of COVID-19 spread and to maintain a minimum distance of 2 meters and not to interact directly with other people and to avoid mass gathering (Buana, 2020). The increase of the number of positive cases of COVID-19 has an impact on the field of education. Some steps are taken through imposing physical distancing by means of distance learning, by utilizing various information technologies. This policy makes teachers, students, and parents have a tremendous impact because of their unpreparedness for problems that emerge suddenly. Teachers are not ready to change the learning system from face-to-face learning to online learning. 
The impact of such technology includes not only the tangible benefits of new digital technology, but also the implications of what is possibly the largest and fastest changing change in individual, social and economic relations and power structures that humanity has ever faced. Online learning is a term that has become frequently used since the pandemic, although in fact the term has a meaning not different from e-learning (Sujarwo, Sukmawati, Akhiruddin, Ridwan and Siradjuddin, 2020; Rasmitadila, Aliyyah, Rachmadtullah, Samsudin, Syaodih, Nurtanto and Tambunan, 2020).

For a teacher, digital learning in the learning process in primary schools has become a new challenge during the COVID-19pandemic. Digital learning during the COVID-19 pandemic uses the web or digital. Various media can also be used to support the implementation of digital learning (Imania, 2019). For example, the use of virtual Google Classroom, Edmodo, Teacher Room, and so on. Even online learning can be done through social media such as Facebook and Instagram (Kumar and Nanda, 2018). Milman (2015) says that in using digital technology, teachers and students are in different places during the learning process.

Learning in the digital generation, students are required to do assignments by searching for information through online media. Thus, teachers can control the number of tasks that have been given to students regardless the time carried out (Prensky, 2001). By doing so, students are no longer late in submitting the assignments given by the teacher in the online learning process. This is the basis for communicating between teachers and students without being directly involved in the online learning process during the pandemic

Through various learning media platforms such as WhatsApp make it possible for teachers monitor students' learning progress during online learning through class groups. Through WhatsApp teacher can provide various information during online learning. At the time of COVID-19, many schools walked around so that teachers are asked to model singles of face-to-face learning online learning (Moorhouse, 2020; Pace, Pettit, Stacie and Barker, 2020). This is based on figure 2 of the platform that teachers use in online programming. The first obstacle is the condition of parents who overuse many WhatsApp (WA) groups application.

Many students across the country do not have an access to computers and the internet which means that distance learning is not an option for them. The barriers to educational technology can be divided into several categories. Students' barriers include more selfdiscipline required by students, less contact with educators and peers, special needs by students and printing costs. Some of the obstacles faced in online learning include: 1) students' parents use WhatsApp (WA) application more frequently and 2) the internet network is often unstable or bad. It is noted that the online learning process is done by giving assignments to students.

This is one of the factors causing the teachers difficult to keep in mind about the learning process during the outbreak of the Corona virus. Psychological disorders can occur due to the increased stress, anxiety and other disorders. Therefore, when giving assignments teachers must take account the students' condition. The point is, giving assignments should be humane and able to measure the abilities of students. At school or at campus, which are all neatly systemized, the situation will be different if students are outside the campus or at home, which is outside the system and sometimes difficult to control. The impact of such technology includes not only the tangible benefits of new digital technology, but also the implications of the biggest and fastest changes in individual, social and economic relationships, and power structures that humanity have ever faced. 
During this COVID-19 pandemic, educators are asking how they should assess students to learn. It is recommended to put various exploratory assignments, such as tasks that involve product and problem-based learning. Wormeli (2020) suggests teachers to use more authentic assessment in online learning because it allows students to multiply a way to show understanding.

Suteki (2020) states that before the Corona virus outbreak, discourses, policies and socialization of era 4.0 had not received significant support for the digital transformation of Indonesian education. The Corona virus outbreak has had a tremendous impact in the field of education. We all certainly do not want conditions like this to last too long. We hope and pray that the COVID-19 pandemic will soon pass and we can return to normal activities. Despite the large and many negative impacts of Covid-19 on various sectors and lines of human life, we still have to fight for the future, especially efforts to educate the Indonesian generation for a better future.

Teachers in online learning must be able to convince students and parents to be directly involved in online learning. According to Jamilah (2020b), a synchronous learning is one of the efforts made by teachers in increasing success in online learning (Ball, 2020). Similar to providing learning material to normal classrooms, online learning must include various tasks and jobs given to students during a pandemic. The impact of online learning for students includes not having an internet quota or having learning media such as cellphones, laptops and computers (Madrim, 2020).

Argues that to overcome various problems faced in online learning collaboration is needed among parents, students, and teachers during the learning process. For this reason, it is necessary to use various forms of media platforms in the learning process. The covenant copes with the learning time, the media used in the process (Jamilah, 2020b). This is expected to overcome various problems and how teachers and students apply learning media during COVID-19 and can interact directly with their teachers. This suggestion is very appropriate because it is a necessity when learning (Albeblisi and Yusop, 2018; Ali and Magalhaes, 2008; Yunus and Rezki, 2020). Therefore, schools set policies in formulating distant learning requirements for their schools. Also, there are no instructions from the Ministry of Education, so that the distant learning is conducted by teachers is varied (Tuncer and Tanas, 2011). However, it does meet the minimum requirements for studying application.

\section{CONCLUSION}

Based on the results of research and discussion that have been explained previously, several things can be concluded. The obstacle faced in learning during the pandemic is that various media platforms cannot be used directly. This is due to the geographical conditions in which students live where many students cannot get good internet access let alone most of the economic conditions of the students' family are unable to facilitate digital learning with various online learning platforms. Digital learning can be said to be successful if teachers have confidence and readiness in digital learning, especially with regards to the mastery of technology and the use of digital platforms owned by each teacher. Parents can see firsthand the activities and learning materials learned by their children at home. Therefore, it can be said that there is a positive side and the word step forward in terms of technology in the process learning. 


\section{REFERENCES}

Bal, M. (2018). Reading and Writing Experiences of Middle School Students in the Digital Age: Wattpad Sample. International Journal of Education and Literacy Studies, 6(2), 89. https://doi.org/10.7575/aiac.ijels.v.6n.2p.89

Al-rahmi, W. M., Othman, M. S., \& Mi Yusuf, L. (2015). The Effectiveness of Using ELearning in Malaysian Higher Education: A Case Study Universiti Teknologi Malaysia. Mediterranean Journal of Social Sciences, 6(5). https://www.richtmann.org/journal/index.php/mjss/article/view/7686

Albeblisi, N.A., \&Yusop, F. . (2018). Secondary School Students'Use of and attitudes toward online Mathematics Homework. Tojet - The Turkish Online Jurnal of Educational Techonology, 17(1), 144-153.

Ali, G., \& Magalhaes, R. (2008). Barries to implementing e leraning: A Kuwaiti case study. International Journal of Training and Development. https://doi.org/10.1111/j.14682419.2007.00294.X

Basilaia, G., \& Kvavadze, D. (2020). Transition to Online Education in Schools during a SARS-CoV-2 Coronavirus (COVID-19) Pandemic in Georgia. Pedagogical Research, 5(4). https://doi.org/10.29333/pr/7937

Bauerlein, M. (2008). Online Literacy is a lesser kind: Slow reading counterbalances Web skimming. The Chronicle of Higher Education, 55(4).

Buana, D. R. (2020). Analisis Perilaku Masyarakat Indonesia dalam Menghadapi Pandemi Virus Corona (Covid-19) dan Kiat Menjaga Kesejahteraan Jiwa. Salam: Jurnal Sosial Dan Budaya Syar-I, 7(3), 217-226.

Chaeruman, U. A., Wibawa, B., \& Syahrial, Z. (2020). Development of an instructional system design model as a guideline for lecturers in creating a course using blended learning approach. International Journal of Interactive Mobile Technologies (iJIM), 14(4), 164-182

Fong, M. W., Gao, H., Wong, J. Y., Xiao, J., Shiu, E. Y. C., Ryu, S., \& Cowling, B. J. (2020). Nonpharmaceutical measures for pandemic influenza in nonhealthcare settings - social distancing measures. Emerging Infectious Diseases, 26(5), 976. https://doi.org/https://doi.org/10.3201/eid2605.190995

Harjanto, T., \& Sumunar, D. S. E. W. (2018). Tantangan Dan Peluang Pembelajaran Dalam Jaringan: Studi Kasus Implementas Elok (E-Learning: Open For Knowledge Sharing) Pada Mahasiswa Profesi Ners. Jurnal Keperawatan Respati Yogyakarta, 5, 24-28. https://doi.org/http://dx.doi.org/10.35842/jkry.v5i0.282

Imania, K. A. N. (2019). Rancangan Pengembangan Instrumen Penilaian Pembelajaran Berbasis Daring. Jurnal PETIK, 5, 31-47.

Jamilah. (2020a). Guru Profesional di Era New Normal: Review Peluang dan Tantangan dalam Pembelajaran Daring. Premiere Educandum: Jurnal Pendidikan Dasar Dan Pembelajaran, 10(2), 238-247. https://doi.org/https://doi.org/10.25273/pe.v10i2.7494

Jamilah. (2020b). Penggunaan media daring selama masa pandemi covid 19 di Sekolah Dasar Integral Luqman Alhakim Sumenep Society 5.0. Prosiding Seminar Dan Diskusi Nasional Pendidikan Dasar "Transformasi Pendidikan Menyogsong SDM Di Era.

Joan S. Ash, P. Zoë Stavri, Gilad J. Kuperman, M. (2003). A Consensus Statement on Considerations for a Successful CPOE Implementation. Journal of the American Medical Informatics Association, 10(3), 229-234. https://doi.org/10.1197/jamia.M1204 
Juliantari, N. K., Sudarsana, I. K., Sutriyanti, N. K., Temon Astawa, I. N., Hendrawathy Putri, I. D. A., \& Saddhono, K. (2018). Educational Games Based in Information Technology as Innovation Evaluation Activity in Learning. Journal of Physics: Conference Series, $\quad 1114(1)$. https://doi.org/https://doi.org/10.1088/17426596/1114/1/012041

Ketut Sudarsana, I., Pusparani, K., Selasih, N. N., Juliantari, N. K., \& Wayan Renawati, P. (2019). Expectations and challenges of using technology in education. ..Journal of Physics: Conference Series, 1175(1). https://doi.org/https://doi.org/10.1088/1742$6596 / 1175 / 1 / 012160$

Kumar, V., \& Nanda, P. (2018). Social Media in Higher Education. International Journal of Information and Communication Technology Education. https://doi.org/https://doi.org/10.4018/ijicte.2019010107

Lathipatud Durriyah, T., \& Zuhdi, M. (2018). Digital Literacy With EFL Student Teachers: Exploring Indonesian Student Teachers' Initial Perception About Integrating Digital Technologies Into a Teaching Unit. International Journal of Education and Literacy Studies, 6(3), 53. https://doi.org/https://doi.org/10.7575/aiac.ijels.v.6n.3p.53

Madrim, S. (2020). KPAI: Siswa keluhkan pembelajaran berat di tengah wabah corona. VOA Indonesia.

Mailizar, Almanthari, A., Maulina, S., \& Bruce, S. (2020). Secondary School Mathematics Teachers' Views on E-learning Implementation Barriers during the COVID-19 Pandemic: The Case of Indonesia. Eurasia Journal of Mathematics, Science and Technology Education, 16(7). https://doi.org/10.29333/ejmste/8240

Miles, M. B., Huberman, A. M., \& Saldana, J. (1994). Data analysis qualitative a methods sourcebook. SAGE.

Milman, N. B. (2015). Distance Education. In International Encyclopedia of the Social \& Behavioral Sciences: Second Edition. https://doi.org/https://doi.org/10.1016/B978-0-08097086- 8.92001-4

Moorhouse, B. L. (2020). Adaptations to a face-to-face initial teacher education course 'forced' online due to the COVID-19 pandemicNo Title. Journal of Education for Teaching. https://doi.org/10.1080/02607476.2020.1755205

Pace, Christi; Pettit, Stacie K.; and Barker, K. S. (2020). Best Practices in Middle Level Quaranteaching: Strategies, Tips and Resources Amidst COVID-19. Becoming: Journal of the Georgia Association for Middle Level Education, 31(1). doi: 10.20429/becoming.2020.310102

Prensky, M. (2001). Digital Natives, Digital Immigrants. On The Horizon, 2-4.

Ramadhani, R. \& Fitri, Y. (2021). EPUB3 based mathematical e-modules using the Sigil application as a solution in teaching and learning process through covid-19 pandemic. Formatif: Jurnal Ilmiah Pendidikan MIPA, $11 \quad$ (1): 35-48. http://dx.doi.org/10.30998/formatif.v11i1.6826

Rasmitadila, Aliyyah, R. R., Rachmadtullah, R., Samsudin, A., Syaodih, E., Nurtanto, M., \& Tambunan, A. R. (2020). The perception of primary school teachers of online learning during the covid-19 pandemic period: A case study in IndonesiaNo Title. Journal of Ethnic and Cultural Studies, 7(2), 90-109.

Selwyn, N. (2016). Minding Our Language: Why Education and Technology is Full of Bullshit ... and What Might be done about it. Learning, Media and Technology, 41(3), 437-443. https://doi.org/10.1080/17439884.2015.1012523 
Sujarwo, Sukmawati, Akhiruddin, Ridwan, \& Siradjuddin, S. (2020). An analysis of university students" perspective on online learning in the midst of Covid-19 pandemicNo Title. Jurnal Pendidikan Dan Pengajaran, 53(2), 125-137.

Suteki. (2020). Covid-19 Picu Percepatan Transformasi Digital Pendidikan Indonesia.

Taha M, Abdalla M, Wadi M, K. H. (2020). Curriculum delivery in Medical Education during an emergency: A guide based on the responses to the COVID-19 pandemic o Title. MedEdPublish, 9(1), 69. https://doi.org/10.15694/mep.2020.000069

Tjandra, D. S. (2020). Impelementasi Pembelajaran Pendidikan Agama Kristen di Abad 21. Jurnal Pendidikan Agama Kristen, 1(1), 1-10.

Tuncer, M., \& Tanas, R. (2011). The evaluation of Academicians' views on distance education programs (The samples of firat and Tunceli universities)No Title. Elementary Education Online, 10(2), 776-784.

Wisudawati, N. et. al. (2020). Teacher 's Perception Of The Application Of Edmodo As. Jurnal Riset Pendidikan Dasar, 3, 87-96.

Yunus, N. R., \& Rezki, A. (2020). Kebijakan Pemberlakuan Lockdown Sebagai Antisipasi Penyebaran corona virus covid-19No Title. SALAM: Jurnal Sosial \& Budaya Syar-I, 7(3), 227-238. https://doi.org/10.15408/sjsbs.v7i3.15083

Zaharah, Z., \& Kirilova, G. I. (2020). Impact of Corona Virus Outbreak Towards Teaching and Learning Activities in IndonesiaNo Title. SALAM: Jurnal Sosial Dan Budaya SyarI, 7(3). https://doi.org/10.15408/ sjsbs.v7i3.15104 